\title{
India's National Security a
}

Sumit Ganguly

The Oxford Handbook of Indian Foreign Policy

Edited by David M. Malone, C. Raja Mohan, and Srinath Raghavan

Print Publication Date: Jul 2015

Subject: Political Science, International Relations, Public Policy

Online Publication Date: Dec 2015 DOI: 10.1093/oxfordhb/9780198743538.013.11

\begin{abstract}
Keywords
Foreign and defence policy overlap in most countries, and India is no exception. This chapter traces the origins of India's national security policies and discusses key turning points. It argues that the first major shift in the country's defence policies took place in the immediate aftermath of the 1962 Sino-Indian border war. In the wake of this conflict the country embarked upon a substantial program of military modernization. It also focuses on a series of extant threats that the country confronts, the policies and strategies that have been adopted to address them, and their limitations and prospects. The chapter also addresses the question of India's military industrial base and its shortcomings. The final section focuses on the key challenges that confront the country and are likely to shape the course of its national security policies.
\end{abstract}

Keywords: India, national security policy, threats, military industrial base, Sino-Indian war

\section{The Legacies of Colonialism and Partition}

INDIA'S emergence in the global order was part of the early wave of the European decolonization process. It came about both as a consequence of the growth of the Indian nationalist movement as well as the inability of the United Kingdom to sustain colonial rule in the wake of its exhaustion as a consequence of the ravages of the Second World War. The country also became independent at a time when the fleeting and exigent cooperation between the United States and the Soviet Union during the Second World War came to a close and the international order witnessed the beginning of the Cold War. As early as July 1947, a month before India's independence, the noted American diplomat George Kennan had pseudonymously published his famous article, "The Sources of Soviet Conduct', a document that would soon become the intellectual basis of the US strategy of containment directed against possible Soviet expansionism. 
Deft Pakistani diplomacy designed solely to balance India's greater capabilities, and a perceived threat, helped focus American attention on the region. The forging of the USPakistan alliance in 1954 was to have significant adverse consequences for India's national security and would also contribute to the estrangement of the two countries (McMahon 1996).

It is important to underscore this politico-strategic backdrop because it had a significant impact on the evolution of India's security policies. The United States, focused on possible Soviet designs on Western Europe and East Asia, paid scant attention to India. The Soviets, still under Stalin's grip, saw India through the lens of a doctrinaire ideology, and thereby attached little significance to the country in their strategic calculations (Donaldson 1974). Indeed, it was not until his demise that his successors shifted their perspective on India's position in the Cold War international order.

(p. 146) At a national level, it is virtually impossible to discuss the genesis of India's security policies without taking into account the role of the British colonial heritage and the impact of the Partition of India. Furthermore, as recent scholarship has revealed, British hostility toward India had important and deleterious consequences for India especially because of British machinations in favor of Pakistan on the vexed question of the status of the Princely State of Jammu and Kashmir (Dasgupta 2002).

Finally, and as many commentators have discussed at length, few individuals had as much of an impact on the shaping of post-independence India's foreign and security policies as its first Prime Minister Jawaharlal Nehru. In the absence of a significant cohort of individuals in the Indian Cabinet who had substantial knowledge of and experience with international affairs, Nehru swiftly emerged as primus inter pares. Consequently, his imprint on India's foreign and security policies was considerable from the very outset.

Contrary to some recent assessments, Nehru's vision of global order, enshrined in the adoption of a policy of non-alignment, was not merely a deft, instrumental strategy. Instead it reflected his deep-seated beliefs about global order. Indeed, a perusal of his writings on international politics supports such a conclusion (Nehru 2011). Nehru, who pursued an ideational foreign policy, had visions of fundamentally transforming the global order. Such an order would promote decolonization and self-determination, hobble the use of force in international politics, boost universal nuclear disarmament, and reduce global inequalities.

\section{The Persistence of Key Security Challenges}

\section{External Threats}

It is intriguing to note that the key national security challenges that India confronted after independence, though not identical, have remained somewhat constant. Three such subjects merit discussion: two of them are external and one domestic. The external threats emanate from Pakistan and the People's Republic of China (PRC). The internal 


\section{India's National Security}

threat, which has metamorphosed over the decades through multiple manifestations, involves both ethnic and class differences that pose a challenge to India's national integrity and cohesion.

The most immediate national security threats that it faced emanated from Pakistan, which advanced an irredentist claim to the state of Jammu and Kashmir (Ganguly 2001). After three wars (1947-8, 1965, and 1999) and multiple crises, Pakistan is no closer toward the realization of its goal. Nevertheless, it has far from abandoned its claim to the state and has, at least since the 1980s, resorted to an asymmetric war strategy to raise for India the costs of keeping the portion of the state that it currently controls (Swami (p. 147) 2006). Furthermore, Pakistan's overt acquisition of nuclear weapons shortly after India's decision to cross that Rubicon may have effectively limited the prospects of fullscale war (Ganguly 2008). However, it may have also created conducive conditions for the pursuit of limited incursions in non-vital regions to test India's resolve and capabilities. In considerable measure, the Kargil War of 1999 may be deemed to be such a 'limited probe' (George and Smoke 1974).

Despite multiple attempts to engage Pakistan in the wake of the Kargil War, even after two subsequent crises in 2001-2 and then again in 2008, little progress has been made toward reaching any rapprochement. Indeed, in 2013 clashes ensued once again along the Line of Control (LoC), the de facto international border, in Kashmir (Bedi 2013d).

A second source of threat, that from the People's Republic of China was perhaps not as immediately apparent in the immediate post-independence era. Furthermore, Prime Minister Nehru had sought to fashion a policy of appeasement to try and avoid a conflict with Indian's northern colossus. ${ }^{1}$ Though neither leader was willing to militarily confront the PRC, the lack of Indian military preparedness proved quite disastrous when the PRC launched an attack on India's Himalayan borders in 1962 (Palit 1992). Shortly thereafter, the PRC moved to forge a closer strategic relationship with Pakistan. In many ways this was cemented when Pakistan conceded a section of the disputed state of Jammu and Kashmir to the PRC in 1963 (Garver 2001). Furthermore, the PRC acquisition of nuclear weapons in 1964 spurred India to pursue a nuclear option as early as 1966 under the aegis of the Subterranean Nuclear Explosions Project (Ganguly 2010).

Despite multiple efforts under various regimes in New Delhi to settle the border dispute, the progress on this front has been glacial. Also, apart from the closeness of the Sino-Pakistani relationship and the PRC's involvement in and support for the Pakistani nuclear weapons program, Sino-Indian relations remain fraught. Three issues, in particular, continue to dog the relationship. The first, of course, involves the unresolved border dispute and the PRC's willingness to periodically shift its stance on its territorial claims and resort to probes along the disputed border. The second stems from the presence and activities of the Dalai Lama, the spiritual and temporal leader of the Tibetan exile community in India. Finally, the PRC remains unreconciled to India's status as a nuclear weapons state. This was evident from its hostility toward granting India an exemption from the 
rules of the Nuclear Suppliers Group when the US-India civilian nuclear agreement was about to be consummated in 2008 .

\section{Internal Threats}

The final national security threat that India confronts stems from within. In the wake of independence, its policy-makers were faced with the daunting task of national integration. The nascent government handled this task with remarkable ease and with a minimum use of force (Menon 1955). ${ }^{2}$ Subsequently, it faced rebellions in India's northeast but proved able to contain if not wholly suppress them through an amalgam of force and limited concessions. Later, in considerable part thanks to the shortcomings of its (p. 148) own federal structure as well as dubious choices on the part of its policy-makers, most notably Prime Minister Indira Gandhi, the country saw the rise of an ethnic, secessionist insurgency in the Punjab (Telford 1992). Later, after a long period of uninterrupted peace, an insurrection also erupted in the Indian-controlled segment of the state of Jammu and Kashmir. The origins of this uprising could also be traced to domestic sources. However, within months of its outbreak Pakistan's security establishment chose to enter the fray turning an internal conflict into a externally supported, religiously charged extortion racket (Ganguly 1997).

The Indian state managed to crush the Punjab insurgency using a rather harsh counterinsurgency strategy. It has also managed to restore a modicum of order if not the rule of law in Kashmir (Ganguly and Fidler 2013). Though the underlying grievances were not, for the most part, addressed in the Punjab, a likely recrudescence of the insurgency there is unlikely. In Kashmir, however, the Indian state still faces a deep reservoir of discontent and also cannot escape the possibilities of continued Pakistani interference.

Finally, two sources of domestic violence now dog India. First, the country has seen the renewal of Maoist violence across a significant swath of the country and the emergence of domestic Islamist terror in particular parts thereof. The roots of this Maoist revival are complex and beyond the scope of this chapter (Lalwani 2011). Suffice it to say that it stems from a congeries of factors including the poor quality of governance in various parts of the country, expanding economic disparities, and the mobilization of extant grievances. How the Indian state chooses to respond to this resurgence of Maoist activity will, in considerable measure, determine its future. Thus far, its responses have been piecemeal, sporadic, and, in large measure, uncoordinated. Of course, India's federal structure, to some degree, hobbles the possibility of fashioning a wholly coherent response.

Second, the emergence of domestic Islamist terror also poses a problem to India's political order. Once again, the specific origins of the genesis of Islamist violence in India are well beyond the scope of this analysis. There is some evidence, however, that it can be traced to persistent perceptions of discrimination amongst a younger generation of Indian Muslims, their increased political awareness, and also the possible impact of the pogrom that took place in Gujarat in February 2002. The most radical of these is the Indi- 
an mujahidin who have been deemed to be responsible for a number of terror attacks across the country (Ahuja 2013).

The challenge that this form of radical Islamist violence poses to the Indian polity cannot be understated. If allowed to fester, it could have significant adverse consequences for the body politic. It might enable external powers, most notably Pakistan, to continue to exacerbate existing social fissures. Furthermore, even in the absence of foreign involvement and interference, the persistence of such rents in the social fabric of a poly-ethnic state are inherently undesirable as it constitutes a fundamental basis for social unrest.

A strategy that simply seeks to repress these organizations and most notably the Indian mujahidin, is unlikely to succeed. Instead, any attempt to deal with these terrorist (p. 149) groups must involve a two-pronged approach. At one level, this will obviously involve careful intelligence collection, prompt investigation of attacks, and swift prosecution of the perpetrators. At another, it will require the Indian state to also address underlying grievances that have led to this turn toward the resort to terror.

\section{Capabilities and Their Limitations}

Given these security challenges what are the extant military capabilities of the Indian state? How has it sought to deploy these assets to cope with the present threats? Finally, what are the principal constraints that it confronts in bringing its resources toward meeting these pressures? The coercive power of the Indian state is considerable and a far cry from the days when it lacked the ability to effectively deal with a range of external threats to its territorial integrity.

The current military capabilities of the Indian state are considerable. According to information in the public domain it has 870 combat aircraft, 21 surface combatant vessels, 15 submarine vessels, and over 3,000 main battle tanks. It also has 1,325,000 military personnel and almost an equal number of paramilitary forces (International Institute of Strategic Studies, 2013). Beyond these human and material capabilities, it also has a very substantial military industrial base. It has 39 ordnance factories, nine Defense Public Sector Undertakings, and a network of 52 high-technology research establishments under the aegis of the Defence Research and Development Organisation (DRDO).

However, despite the size of the military-industrial infrastructure, its actual performance has been quite uneven. As a number of scholars and analysts have highlighted, it has suffered from vast cost overruns, it has failed to meet stated targets on a number of occasions, and is not subject to careful, rigorous, dispassionate external scrutiny (Behera 2013). Consequently, despite a long-professed commitment to self-reliance in the arena of weapons acquisitions, the country remains acutely dependent on a range of foreign suppliers for a range of weaponry to equip its armed forces (Kumar 2012).

Among other matters, the country has long struggled to develop an indigenous Light Combat Aircraft. Indeed, it was three decades after the project was launched that it was 
finally flight tested in April 2013 (Menon 2013). Though touted as an indigenous aircraft, General Electric engines power both its versions (Bedi 2013c). Furthermore, its radar, weapons systems, and other key components are also of foreign origin. As of early 2013, the aircraft had yet to receive full operational clearance; a designation that means that it has received the requisite approval to carry weaponry. India's experience in developing a military transport aircraft, Saras, has not been salutary. Of the two test aircraft that were built, the second crashed in 2009 killing all three personnel on board. The efforts at indigenization once again have been far from exemplary as the engine is from Pratt and Whitney of Canada (Francis and Menon 2013).

The problems with this aircraft unfortunately are emblematic of what ails much of India's sprawling defense industrial sector. Indian strategic commentators routinely (p. 150) exhort policy-makers to reduce the country's dependence on foreign suppliers of weaponry. A committee that an important player in India's defense science establishment and subsequent president, A. P. J. Kalam, had headed in the mid-1990s had called for reducing the foreign content of weaponry from 70 to 30 per cent by 2005. However, as of 2013, the figure remained at 70 per cent (M. Joshi 2013). In the foreseeable future, it is hard to envisage how India might be able to reduce its dependence on foreign suppliers given the persistent inability of its domestic military industrial base to meet extant needs on a timely and cost-effective basis.

\section{Policies and Strategies}

To cope with the threat from the PRC, India has deployed twelve mountain divisions along its Himalayan border. The threat to India is compelling and has been underscored as a consequence of a number of statements emanating from high-level sources as well as recent border incidents. India's strategy, as can be discerned from its border deployments, appears to be a combination of a strategy of deterrence through denial and punishment (Snyder 1961).

Along the Himalayan border, India's military deployments, its road improvement efforts, and its creation of a new military base equipped with Sukhoi-30 aircraft in Tezpur, Assam, all suggest that in terms of immediate deterrence of the PRC India's military planners have chosen a strategy of denial (Kashyap 2007). In June of 2013, India's Ministry of Finance gave the nod for the development of a mountain strike corps of around 90,000 troops which would be deployed along the disputed border with the PRC. This approval came in the wake of an incident in which the People's Liberation Army (PLA) had penetrated and set up camp 19 kilometers within the Line of Actual Control in mid-April of 2013. The PLA forces had withdrawn from the Dapsang Valley only after extensive diplomatic negotiations and a tense three-week standoff with the Indian army (Bedi 2013b). These preparations are under way despite New Delhi's unwillingness to ratchet up its public rhetoric when dealing with the PRC on the fraught question of the resolution of the border dispute. 
In pursuit of a form of more general deterrence of the PRC, India is steadily investing in long-range missile capabilities that can strike significant portions of southern China. In fact, the Agni V missile that is currently under development should not only be able to target significant sections of the PRC but is apparently designed to carry multiple warheads (Keck 2013). This Indian deterrent capability is mostly designed to counter the PRC's substantial air capabilities in Tibet including five all-weather airfields. Also, according to a reliable source, the PRC apparently has an undisclosed number of Dong Feng-3 nuclear-capable ballistic missiles in Tibet which are targeted at India (Bedi 2013a).

Furthermore, the Sino-Indian competition is starting to extend well beyond the disputed border and spilling over into India's immediate neighborhood. Through a deft (p. 151) amalgam of diplomatic initiatives, economic incentives, and security arrangements the PRC has made significant inroads into all of India's neighbors. These developments go well beyond the 'all weather' friendship that the PRC has long enjoyed with Pakistan (Sender 2013).

Additionally, a degree of naval competition, at least in incipient form, is now emerging in the Indian Ocean as the People's Liberation Army Navy (PLAN) seeks to extend the reach of its capabilities. It is unlikely that this will abate any time in the foreseeable future. Instead, if the PLAN ramps up its activity and the PLA continues to exert pressure on India's land borders in the Himalayan region, there is every reason to believe that Indian naval planners will seek to broaden and deepen the scope of their current naval cooperation with Singapore, Vietnam, and Japan. These states, as well as various others in NorthEast and South-East Asia entertain significant and growing anxieties about the PLAN's assertiveness in the South China Sea and beyond. Furthermore, a number of them have important maritime boundary disputes with the PRC. Consequently, enhancing naval cooperation with India provides a useful hedge against the PLAN's ability and willingness to flex its capabilities in the region.

India's willingness to enter the fray reflects some ambivalence. Obviously, its policy-makers do not want to get drawn into a regional maritime conflict far from its shores. However, as prominent Indian commentators have argued, it is nevertheless willing to demonstrate that it has the requisite naval capabilities to reassure its new-found friends in South-East Asia (Mohan 2013).

In addition to these states, India has also sought to forge a viable diplomatic relationship with South Korea, a state that it had mostly neglected during much of the Cold War era. However, over the course of the past decade India has successfully managed to fashion a multi-faceted relationship with South Korea. Though neither side sees this relationship as a mechanism for containing the PRC, both have common interest in promoting bilateral trade and investment and, from a strategic standpoint, in keeping a close watch on the Pakistani-North Korean clandestine nuclear weapons network (Brewster 2010).

Though conducted without much fanfare, India has extended its naval reach into the South China Sea. According to analysts who have some familiarity with and knowledge of these Indian naval deployments, India's efforts stem from a combination of both geoeco-

Page 7 of 17

PRINTED FROM OXFORD HANDBOOKS ONLINE (www.oxfordhandbooks.com). (c) Oxford University Press, 2018. All Rights Reserved. Under the terms of the licence agreement, an individual user may print out a PDF of a single chapter of a title in Oxford Handbooks Online for personal use (for details see Privacy Policy and Legal Notice). 


\section{India's National Security}

nomic and geostrategic interests. Specifically, it appears that India's interest in operating in these waters stems from its quest for reliable energy resources especially off the coastal areas of Vietnam, to ensure safe and uninterrupted passage of its ships involved in seaborne trade, and to deny the PRC from asserting any unilateral sway over the region. These interests, from an Indian standpoint, neatly converge because as much as 55 per cent of India's trade takes place through the choke point of the Straits of Malacca and to and from the region of the South China Sea (Scott 2013).

Over the past decade India has sought to engage Pakistan despite incontrovertible evidence of the Pakistani state's involvement with terror. The results of these efforts, however, have been far from encouraging. Multiple rounds of talks have not resulted in (p. 152) any concrete, tangible results and it is far from clear that continuing discussions will lead to better outcomes.

In June 2013, following Nawaz Sharif's election as Prime Minister of Pakistan, hopes in India rose of some possible improvement in relations. Subsequent developments, however, have belied these expectations. It is apparent that despite the emergence of a legitimately elected civilian regime, it is in no position to make any credible commitments to New Delhi. For all practical purposes, the military establishment remains primus inter pares within the Pakistani state and is not about to relinquish its stranglehold over key foreign and security policy issues. Consequently, it is hardly much of a surprise that the newly elected civilian regime has been hamstrung from undertaking any meaningful initiatives to reduce tensions let alone terminate the rivalry with India. In the absence of an endogenous or exogenous shock that fundamentally alters the status of the Pakistani military establishment within the political milieu of the country, it is hard to envisage how a breakthrough might emerge in Indo-Pakistani relations.

Given the asymmetry in military capabilities between the two states, and one that is likely to widen in the future, especially if India can sustain a respectable level of economic growth, it is hardly surprising that the Pakistani military establishment has come to rely on the use of terrorist proxies to inflict significant costs on India (Swami 2006). Despite various efforts, the Indian state, given its many domestic vulnerabilities, has been unable to devise an effective defensive or deterrent strategy to thwart this strategy.

Its defensive efforts along the LoC including the building of a fence have proven unsuccessful in stopping infiltration into Jammu and Kashmir (Swami 2004). Nor has it been able to wholly secure its vast coastline even after the horrific terrorist attack on Mumbai in November 2008 (Polgreen and Bajaj 2009). Consequently, it does not have what is referred to as a strategy of defense through denial. Unfortunately, it has not been able to devise a coherent strategy of defense through punishment or retaliation either. In the wake of the 2001-2 crisis when the country came perilously close to war with Pakistan, it had sought to fashion a military strategy known as 'Cold Start' designed to carry out a limited, swift, sharp retaliatory response in the event of a Pakistan-based terrorist attack on Indian soil. However, as one analyst has argued, the actual ability to implement this strategy has been hamstrung as a consequence of organizational pathologies and inade- 
quate planning (Ladwig 2007-2008). Furthermore, at least one chief of staff of the Indian army has stated that the doctrine does not formally exist (Pubby 2010).

India's policy-makers may have concluded that carrying out this strategy could be fraught with considerable risk. Given Pakistan's stated nuclear doctrine, which calls for a rapid nuclear escalation in the event of a sudden Indian conventional attack, the possibility of the outbreak of a nuclear war is indeed substantial. Pakistan's continuing investment in the development of tactical nuclear weapons further enhances the dangers of a nuclear war stemming from an Indian conventional attack (S. Joshi 2013). Given that Pakistan's nuclear doctrine and capabilities can undermine India's limited war doctrine, it is reasonable to surmise that India has sought to invest in the development of ballistic (p. 153) missile defense capabilities to trump Pakistan's nuclear use plans. With such a shield in place, especially in battlefield circumstances, India could significantly attenuate, if not wholly eliminate, the consequences of any early Pakistani resort to the use of tactical nuclear weapons. It could then resort to an overwhelming strike against Pakistan with its nuclear arsenal largely intact.

Such a strategy, though understandable from the Indian standpoint, is nevertheless unlikely to work. Pakistan, in all likelihood, will not only seek to ramp up the production of its tactical nuclear weapons but will also seek to place them on mobile launchers, disperse them across the country, and resort to both camouflage and deception. Such choices would not only undermine the utility of India's costly investments in ballistic missile defense but could very possibly unravel its strategy of escalation dominance (Topychkanov 2012).

Apart from this troubled bilateral relationship, India's national security interests in the region are also likely to be affected quite dramatically as the International Security Assistance Force, under the aegis of the North Atlantic Treaty Organization, winds down its presence and operations in Afghanistan. India's strategists and diplomatic corps well realize that Pakistan's security establishment will, no doubt, seek to undermine India's hard-won political presence and economic interests in the country.

\section{The Nuclear Gyre}

Apart from conventional threats, the country also needs to cope with two nuclear-armed neighbors. Since the overt acquisition of nuclear weapons, India's policy-makers publicly stated that the country sought to pursue a strategy of 'minimum credible deterrence' (Bastur 2006). Despite this stated commitment to the pursuit of such a strategy, India's actual programs and deployments suggest otherwise.

The creation of a strategic triad composed of long-range nuclear capable aircraft, a suite of land-based intercontinental ballistic missiles (ICBMs) and a submarine-based force goes well beyond the needs of a finite deterrent strategy. More to the point, the country's increasing investment in ballistic missiles defenses in conjunction with a set of robust ICBM capabilities could have significant adverse consequences for both strategic stability 
and crisis management (Kampani 2013). Furthermore, as some knowledgeable commentators have argued, despite the creation of a Strategic Forces Command, the operational dimensions of India's nuclear forces still face a number of serious organizational problems. Among other matters the control of the nuclear warheads are still divided between two civilian scientific agencies: the Bhabha Atomic Research Centre and the DRDO. Simultaneously, the three armed services remain in charge of the relevant combat aircraft, naval assets, and nuclear-capable ballistic missiles. In addition to this organizational anomaly, concerns persist about the actual material infrastructure of India's nuclear assets. These include, but (p. 154) are not limited to, secure communication networks, redundant command and control nodes, safe storage and suitable hideouts for the nuclear force, and reliable transport infrastructure for the secure mobility of warheads, fissile cores, and delivery vehicles (Kampani 2013: 116).

\section{Beyond Immediate Threats}

\section{Strategic Links with the US}

Apart from coping with the threats from Pakistan and the PRC, India's policy-makers have yet to reach a working consensus on the contours of a strategic relationship with the United States. Reaching such an understanding may be quite significant for the future of India's national security. Unfortunately, three forces cast a cloud over any attempt to reach a clear-cut understanding on what might constitute such a working strategic partnership with the United States.

First, at an international level, there is little question that the 'shadow of the past' continues to dog the relationship. During the Cold War, as is well known, the two sides were frequently at odds. India was of little or no strategic significance to the United States and was often treated with a mixture of disdain and disregard. India, of course, had successfully fashioned a strategic partnership with the Soviet Union and this, in turn, had blighted any prospect of strategic convergence with the United States.

Second, and stemming from this strategic disjuncture, India's policy-makers were dismayed at the fitful support for Pakistan during the Cold War. Some instances of American support for Pakistan had seriously impinged upon India's security interests. Even after the Cold War's termination and a marked transformation of Indo-US strategic ties, the US relationship with Pakistan continues to rankle in New Delhi. Specifically, despite much discussion, the two sides cannot seem to find common ground about how best to deal with the Pakistani military establishment's willingness to use terror as part of its asymmetric war strategy against India. Despite persistent pleas from India, the United States has not proven willing or able to bring suitable pressure to bear on Pakistan to dismantle an extensive terror network. At most, US officials have been willing to publicly state that Pakistan's intelligence services have been involved in supporting terrorist attacks on Indian diplomatic and other assets in Afghanistan (Mazzetti and Schmitt 2008). 


\section{India's National Security}

Third and finally, a segment of Indian domestic opinion and specifically those on India's political left, remain deeply skeptical about a US-India strategic partnership. Even though their political salience is clearly waning, they nevertheless constitute an important stumbling block along the pathway toward robust Indo-US strategic cooperation. In a related vein, another segment of India's attentive public, though not explicitly on the ideological left, also looks askance at enhancing strategic (p. 155) cooperation with the United States on the putative grounds that it would compromise India's commitment to strategic autonomy.

These constraints notwithstanding, Indo-US strategic cooperation has moved forward, albeit fitfully, since the Cold War's end. It is beyond the scope of this analysis to carefully summarize the various steps that have been taken to promote such cooperation. However, the United States, despite its reliance on Pakistan especially after the terrorist attacks of 11 September 2001, and its subsequent ventures on the ground in Afghanistan, has sought to court India principally as a potential strategic hedge against the PRC.

Clearly with an eye toward eliciting India's cooperation, the Bush administration had chosen to overturn a decades-long policy of seeking to induce India to dispense with its nuclear weapons program. To that end, it expended considerable domestic as well as international political capital to forge a civilian nuclear agreement with India (Ganguly and Mistry 2006). Unfortunately, from the US standpoint, this attempt to engage India through the lifting of a range of sanctions related to its nuclear infrastructure did not result in a wider, cooperative strategic relationship (Burns 2007). Given the constraints of India's domestic politics, the strong streak of independence that permeates India's political culture, and the lingering memories of the US involvement with Pakistan during a significant segment of the Cold War years, all act as important constraints on the deepening of the Indo-US strategic partnership.

Might some of these factors lose their salience in the years ahead? It is difficult to provide a definitive answer to this question. Though much progress has been made in IndoUS relations over the past decade, political attitudes within India do not change swiftly. That said, three important developments are likely to shape the future of US-India strategic cooperation.

First, such cooperation will depend on the scope and pace of the US drawdown in Afghanistan after 2014. Indian policy-makers, quite understandably, are concerned that the end of the US military presence in Afghanistan may well open the floodgates to the expansion of Pakistan's military influence within that country and the possible return of a neo-Taliban regime. Such an outcome could well have significant adverse consequences for India's standing in the country and once again make it a haven for various anti-Indian terrorist organizations.

Second, a great deal depends on India's own reactions to the US 'rebalancing' strategy toward Asia. Thus far, India's policy-makers have expressed limited enthusiasm for this strategic shift despite an overt US attempt to make common cause with India. Though quietly pleased with the US interest in refocusing its attention to Asia, India's policy-mak-

Page 11 of 17

PRINTED FROM OXFORD HANDBOOKS ONLINE (www.oxfordhandbooks.com). (c) Oxford University Press, 2018. All Rights Reserved. Under the terms of the licence agreement, an individual user may print out a PDF of a single chapter of a title in Oxford Handbooks Online for personal use (for details see Privacy Policy and Legal Notice). 
ers simply do not wish to become a strategic surrogate for the United States as it seeks to address possible Chinese revanchist behavior in Asia (Ricks 2014).

Third and finally, much depends on how the US-India defense cooperation efforts evolve. Most recently, the US policy-makers were disappointed with India's decision to award the contract for 126 medium multi-role combat aircraft to Dassault Aviation of France (Clark 2012). According to a knowledgeable source, the decision was made solely on technical grounds after a careful scrutiny of the capabilities of the various (p. 156) competitors for the lucrative contract (Tellis 2011). However, there is some lingering sentiment in US policy-making circles that it was politically untenable to award the contract to the United States in the wake of several other recent large ticket weapons sales agreements.

In the past, defense cooperation has been hobbled because of US unwillingness to transfer technology to India. However, this reluctance may now be finally ending. In September of 2013, the outgoing US Deputy Secretary of Defense, Ashton Carter, offered a glimpse into what may constitute a significant departure from past US practices. Specifically, on a visit to India he suggested that the two countries might wish to co-develop the next-generation Raytheon-Lockheed Martin FGM-148 Javelin anti-tank guided missile and also the Electro Magnetic Aircraft Launch System for the Indian navy's future aircraft carriers (Hardy and Bedi 2013). If these or other joint projects come to fruition they would mark a dramatic departure from past limitations on defense cooperation and provide a solid foundation for robust US-India defense cooperation and thereby help meet many of India's extant defense technology needs.

\section{Russian Federation}

India had enjoyed a mostly untroubled strategic partnership with the Soviet Union during much of the Cold War and especially after the early 1970s. This relationship, though quite beneficial in terms of weapons acquisitions, was not entirely bereft of costs. India, for example, felt compelled to maintain a studied public silence on the Soviet invasion and occupation of Afghanistan because of its acute dependence on both Soviet markets and arms transfers. Subsequently, India's decision, apparently at the behest of the Soviet Union, to support the Vietnamese-supported regime of Heng Samrin in Cambodia (Kampuchea) proved costly in terms of India's quest to obtain observer status with the Association of South-East Asian Nations.

The Cold War's end significantly attenuated this relationship. As the Soviet Union started to slowly unravel, President Mikhail Gorbachev made clear that he was no longer willing to uncritically offer diplomatic and strategic support to India on issues of importance. Matters worsened considerably under Boris Yeltsin who evinced scant interest in India.

Indeed, the Indo-Russian strategic relationship has not been fully revived under President Vladimir Putin. Though it has been resuscitated, few Indian policy-makers entertain any expectations that it can be restored to its Soviet era status. Instead, it is now on a narrower footing, focused primarily on a renewed arms transfer relationship but one hardly free from various troubles. India and Russia are developing a fifth-generation aircraft and 
co-producing the Brahmos missile. In November 2013, India finally took receipt of the retooled aircraft carrier Admiral Gorshkov (renamed INS Vikramaditya) after substantial delays and cost overruns (Pandit 2013). Obviously, given the long history of the arms transfer relationship with the former Soviet Union, India will not be able to promptly end its dependence on the principal successor state, Russia. Furthermore, some domestic constituencies, which have worked for an extended time span with their (p. 157) Russian counterparts may argue that the Soviet Union was and Russia remains a more reliable supplier than the United States or other Western powers, the troubles with the aircraft carrier notwithstanding.

\section{Conclusion}

After six decades of independence, India's record on its national security policies presents distinctly mixed results. It has, barring the debacle of the 1962 Sino-Indian border war, managed to fend off attempts to challenge its territorial integrity. It has also managed to ward off internal secessionist threats even though, as argued, a number of them persist.

The country has created a defense industrial base but its ability to deliver products that meet the expectations of the armed forces has frequently fallen short. These state-run industries have also proven to be hopelessly inefficient in the use of allocated funds and are known for cost overruns on any number of projects. In the absence of greater institutional accountability or the introduction of substantial private competition it is hard to envisage that the sector can be reformed to ensure that it can demonstrate greater institutional efficacy.

Finally, though the country chose to end its policy of nuclear ambiguity in 1998, it has yet to fashion a wholly coherent nuclear strategy. Instead, despite the professed commitment to a 'credible minimum deterrent', its nuclear forces are expanding in a fashion that hardly appears compatible with such a professed goal. The country's failure to forthrightly tackle this component of its national security apparatus leaves it exposed to considerable risk given the sheer significance of a nuclear deterrent.

\section{References}

Ahuja, R. (2013). 'Indian Mujahideen Story: Modest Origins to Suicide Attacks', The Hindustan Times, 24 February.

Basrur, R. M. (2006). Minimum Credible Deterrence and India's Nuclear Security. Palo Alto, CA: Stanford University Press.

Bedi, R. (2013a). 'Border Dispute Shows Strain in Indo-China Relations', IHS Jane's Defense Weekly, 26 June.

Bedi, R. (2013b). 'India Approves Mountain Strike Corps', IHS Jane's Defense Weekly, 5 June. 
(p. 158) Bedi, R. (2013c). 'India Finally Pulls Plug on Kaveri Engine', IHS Jane's Defense Weekly, 31 January.

Bedi, R. (2013d). 'Indian Army Fights “Pakistan-Backed” Militants on LoC', IHS Jane's Defense Weekly, 9 October.

Behera, L. K. (2013). 'Indian Reforms: Lacking the Punch', IHS Jane's Defense Weekly, 9 October.

Brewster, D. (2010). 'India's Developing Relationship with South Korea: A Useful Friend in East Asia', Asian Survey, 50(2): 402-25.

Burns, R. N. (2007). 'America's Strategic Opportunity with India: The New U.S.-India Partnership', Foreign Affairs, 86(6): 131-46.

Clark, N. (2012). 'Dassault Chosen to Bid on $\$ 10$ Billion Indian Military Contract', The New York Times, 31 January.

Dasgupta, C. (2002). War and Diplomacy in Kashmir, 1947-48. New Delhi: Sage.

Donaldson, R. H. (1974). Soviet Policy Toward India: Ideology and Strategy. Cambridge, MA: Harvard University Press.

Francis, L. and Menon, J. (2013). 'India's Indigenous Aircraft Come Up Short', Aviation Week \& Space Technology, 11 February.

Ganguly, S. (1997). The Crisis in Kashmir: Portents of War, Hopes of Peace. New York: Cambridge University Press.

Ganguly, S. (2001). Conflict Unending: India-Pakistan Tensions since 1947. New York: Columbia University Press.

Ganguly, S. (2008). 'Nuclear Stability in South Asia', International Security, 33(2): 45-70.

Ganguly, S. (2010). 'India's Nuclear Free Dream', The Diplomat, 22 April. < http://

thediplomat.com/2010/04/22/india\%E2\%80\%99s-nuclear-free-dream/> (accessed 26 September 2013).

Ganguly, S. and Fidler, D. (eds.) (2013). India and Counterinsurgency: Lessons Learned. London: Routledge.

Ganguly, S. and Mistry, D. (2006). 'The Case for the US-India Nuclear Agreement', World Policy Journal, 23(2): 11-19.

Garver, J. (2001). Protracted Contest: Sino-Indian Rivalry in the Twentieth Century. Seattle, WA: University of Washington Press.

George, A. and Smoke, R. (1974). Deterrence in American Foreign Policy: Theory and Practice. New York: Columbia University Press. 


\section{India's National Security}

Hardy, J. and Bedi, R. (2013). 'Carter Signals New Era of Indo-US Co-operation', IHS Jane's Defense Weekly, 25 September.

International Institute of Strategic Studies (2013). The Military Balance 2013. London: International Institute of Strategic Studies.

Joshi, M. (2013). 'India's Defense Needs FDI', The Hindu, 14 May.

Joshi, S. (2013). 'Pakistan's Tactical Nuclear Nightmare: Déjà Vu?' The Washington Quarterly, 36(3): 159-72.

Kampani, G. (2013). 'India: The Challenges of Nuclear Operationalization and Strategic Stability', in Strategic Asia 2013-2014: Asia in the Second Nuclear Age, ed. A. J. Tellis, A. M. Denmark, and T. Tanner. Seattle, WA: National Bureau of Asian Research, 99-130.

Kashyap, S. G. (2007). 'Goodbye MiG 21, New Look Tezpur Air Base to Welcome Latest Aircraft', The Indian Express, 5 September.

Keck, Z. (2013). 'India's Agni-V ICBM to Carry Multiple Nuclear Warheads', The Diplomat, 31 May. <http://thediplomat.com/flashpoints-blog/2013/05/31/indias-agni-v-icbmto-carry-multiple-nuclear-warheads/> (accessed 12 November 2013).

Kennedy, P. (1989). Strategy and Diplomacy, 1870-1945. New York: HarperCollins.

(p. 159) Kumar, H. (2012). 'Why Has India Become the World's Top Arms Buyer?' The New York Times, 21 March. <http://india.blogs.nytimes.com/2012/03/21/why-has-indiabecome-the-worlds-top-arms-buyer/?_r=0 > (accessed 10 November 2013).

Ladwig, W. C. (2007-2008). 'A Cold Start for Hot Wars? The Indian Army's New Limited War Doctrine', International Security, 32(3): 158-90.

Lalwani, S. (2011). 'India's Approach to Counterinsurgency and the Naxalite Problem', Combating Terrorism Center Sentinel, 4(10). <http://newamerica.net/node/61304> (accessed 25 September 2013).

McMahon, R. J. (1996). The Cold War on the Periphery: The United States, India, and Pakistan. New York: Columbia University Press.

Mazzetti, M. and Schmitt, E. (2008). 'Pakistanis Aided Attack in Kabul, US Officials Say', The New York Times, 1 August.

Menon, J. (2013). 'Latest Version of Indian Light Combat Aircraft Takes Flight', Aviation Week, 2 April. <http://www.aviationweek.com/Article.aspx?id=/article-xml/ awx_04_02_2013_p0-564715.xml\#> (accessed 14 November 2013).

Menon, V. P. (1955). The Story of the Integration of the Indian States. London: Longmans, Green \& Company. 
Mohan, C. R. (2013). 'An Uncertain Trumpet? India's Role in Southeast Asian Security', India Review, 12(3): 134-50.

Nehru, J. (2011). China, Spain and the War [Reproduction]. Charleston, SC: Nabu Press.

Palit, D. K. (1992). War in High Himalaya: The Indian Army in Crisis, 1962. London: C. Hurst \& Company.

Pandit, R. (2013). 'INS Vikramditya will be a Game Changer', The Times of India, 14 November.

Polgreen, L. and Bajaj, V. (2009). 'India's Guard is Up, but Weaknesses Remain', The New York Times, 24 November.

Pubby, M. (2010). 'No “Cold Start” Doctrine, India Tells US', The Indian Express, 9 September.

Ricks, T. E. (2012). 'Why India is so Half-Hearted about the US Rebalance towards Asia', Foreign Policy, 14 August. <http://ricks.foreignpolicy.com/posts/2012/08/14/ why_india_is_so_half_hearted_about_the_us_rebalance_towards_asia $>$ (accessed 16 November 2013).

Scott, D. (2013). 'India's Role in the South China Sea: Geopolitics and Geoeconomics in Play', India Review, 12(2): 51-69.

Sender, H. (2013). 'China's Embrace Offers Pakistan Respite from Isolation', The Financial Times, 13 November.

Snyder, G. H. (1961). Deterrence and Defense: Towards a Theory of National Security. Princeton NJ: Princeton University Press.

Swami, P. (2004). 'Failed Threats and Flawed Fences: India's Military Responses to Pakistan's Proxy War', India Review, 3(2): 147-70.

Swami, P. (2006). India, Pakistan and the Secret Jihad: The Covert War in Kashmir, 19472004. London: Routledge.

Telford, H. (1992). 'The Political Economy of Punjab: Creating Space for Sikh Militancy', Asian Survey, 32(11): 969-87.

Tellis, A. J. (2011). Dogfight! India's Medium Multi-Role Combat Aircraft Decision. Washington, DC: Carnegie Endowment for International Peace.

Thompson, M. (2013). 'Hyderabad: India's Hidden Massacre', BBC News Magazine, 24 September. <http://www.bbc.co.uk/news/magazine-24159594> (accessed 25 September 2013). 
Topychkanov, P. (2012). India's Prospects in the Area of Ballistic Missile Defense: A Regional Security Perspective. Working Paper Number 3. Moscow: Carnegie Moscow Center.

\section{Notes:}

(1.) The term 'appeasement' is used here in the pre-Munich sense of the term. See Kennedy (1989).

(2.) A document that was declassified in 2013 revealed an infelicitous dimension of the Indian army role during the 'police action' that led to the integration of the Princely State of Hyderabad into the Indian Union. See Thompson (2013).

\section{Sumit Ganguly}

Sumit Ganguly is a Professor of Political Science, holds the Rabindranath Tagore Chair in Indian Cultures and Civilizations and directs the Center on American and Global Security at Indiana University Bloomington. 